Diversity of Research in Health Journal / Revue de la Diversité de la Recherche en Santé Vol 3, February / Février 2020 - ISSN 2561 - 1666 DOI: 10.28984/drhj.v3i0.296

\title{
Reflections of First Year Nursing Students: The Tango Tower Experience
}

\section{E. Donato, J. Benoit}

Short communication DRHJ/RDRS 2020, 3, pp.129-133

Emily Donato, R.N., B.Sc.N., M.Ed., PhD., Assistant professor, edonato@laurentian.ca

School of Nursing, Faculty of Health, Laurentian University.

Jean Benoit, B.E.P.H

Outdoor Centre Manager, jbenoit@laurentian.ca

School of Human Kinetics, Faculty of Health, Laurentian University.

\begin{abstract}
First year nursing students at Laurentian University are taught self-reflection in the first semester of their program and continue to practice these skills throughout the following years of the program to assist in further developing self-awareness. This promotes a beginning understanding of the self-assessment required for quality assurance of their own practice as mandated by the College of Nurses of Ontario (2015). The purpose of this research was to determine the personal learning and team building skills of first year nursing students participating in an outdoor challenge course, namely, the Tango Tower. The rationale for this research involved the idea that the outdoor challenge course presented a learning opportunity to enhance personal self-awareness and team building skills. This qualitative study involved nursing students who completed self-reflections focusing on how they felt before, during, and after the challenge course experience. 16 first year nursing students consented to have their selfreflections reviewed for this research. A thematic analysis of these reflections demonstrated that the students became more self-aware in how they encounter new situations, learned to trust peers, and improved their communication and team building skills. Implications of this research are that results may be used to inform educators and facilitators in promoting the use of the outdoor challenge course to facilitate student learning, and also to potentially enhance interprofessional student learning by having a variety of professional students involved in team building activities.
\end{abstract}

Keywords: Team-building, nursing students, self-reflection, outdoor challenge course. 
Diversity of Research in Health Journal / Revue de la Diversité de la Recherche en Santé Vol 3, February / Février 2020 - ISSN 2561 - 1666 DOI: 10.28984/drhj.v3i0.296

\section{Résumé}

Les étudiants de première année en sciences infirmières à l'Université Laurentienne apprivoisent une démarche de réflexion sur soi au cours du premier semestre de leur programme et continuent de mettre en pratique ces compétences tout au long des années suivantes du programme pour les aider à perfectionner leur introspection. Le but de cette recherche était de déterminer les aptitudes personnelles d'apprentissage et de cohésion d'équipe des étudiants de première année en sciences infirmières qui participent à un cours de défi en plein air, soit la Tour d'escalade Tango. La thèse de cette recherche reposait sur l'idée que le cours de défi en plein air offrait une occasion d'apprentissage qui permettait d'améliorer la conscience de soi et les aptitudes à travailler en équipe. Cette étude qualitative a fait appel à des étudiantes et étudiants en sciences infirmières qui ont mené une réflexion personnelle sur ce qu'ils avaient ressenti avant, pendant et après l'expérience de ce cours qui représentait un véritable défi. Seize étudiants de première année en sciences infirmières ont consenti à ce que leurs réflexions personnelles soit examinées dans le cadre de cette recherche. Une analyse thématique de ces réflexions a démontré que les élèves ont pris davantage conscience de la façon dont ils font face à de nouvelles situations, qu'ils ont appris à faire confiance à leurs pairs et qu'ils ont amélioré leurs compétences en communication et en travail d'équipe. Les résultats de cette recherche peuvent être utilisés pour informer les éducateurs et les animateurs sur la façon de promouvoir l'utilisation du cours de défi en plein air pour faciliter l'apprentissage des étudiants.

Mots clés : Cohésion d'équipe, étudiants en sciences infirmières, réflexion sur soi, cours de défi en plein air.

\section{Introduction}

Nursing students in undergraduate nursing programs are taught to systematically reflect on their learning and clinical experiences following a guideline or model of reflection. First-year nursing students at Laurentian University are taught reflection skills in the first semester of their program to undertake self-assessment required for quality assurance of their own practice, which continues throughout their nursing practice thus ensuring quality of patient care. The opportunity arose to have first-year nursing students involved in an outdoor challenge course involving the Tango Tower, which is situated at the Laurentian University outdoor recreation facility. The challenge course provides activities which students can become involved in at any level and may be viewed as a learning opportunity to enhance personal self-awareness and team-building skills which are necessary for effective nursing practice and improved patient outcomes. The aim of this study was to determine how the Tango Tower experience may facilitate first-year nursing students' self-awareness and team-building skills through reflective practice.

Participation in challenge courses has skyrocketed in recent years, with double digit growth per decade in the last four decades in Canada and the U.S (Smith, 2016). In an analysis of challenge course research, Speelman (2013) found that team development and self-esteem were 
Diversity of Research in Health Journal / Revue de la Diversité de la Recherche en Santé Vol 3, February / Février 2020 - ISSN 2561 - 1666 DOI: 10.28984/drhj.v3i0.296

statistically significant findings for all the research designs reviewed. Another study conducted by Garder and Flood (2006) showed significant differences for all eight Life Effectiveness Questionnaire domains in college students after participating in a one day challenge course experience.

\section{Methods}

Fifty-seven first-year nursing students participated in a 1.5 hour low ropes program. Low ropes courses can be from ground to 13 feet in the air (Rohnke et al., 2007). The student team's problem-solved through a challenge using low ropes while following the instructions of the facilitator.

This evaluation was granted ethical approval by the Laurentian University Research Ethics Board. Students were asked for their consent to have their self-reflections as part of this research 6 months after the course was over. Sixteen students consented to have their selfreflections reviewed for this research. Students were asked to reflect on their feelings prior to the activity, on their actual experience of the Tango Tower activity, and on any new perspectives they may have gained after the activity. The process of thematic analysis was undertaken to identify themes at these different stages of reflection (Braun \& Clark, 2006).

\section{Results}

The following themes in Table 1 were identified for each stage of reflection:

Table 1 Themes

\section{Before the Activity: Awareness of Feelings}

\section{Nervousness about activity.}

"I'm nervous, scared of heights" (R5).

"I was nervous before going because I didn't know what it would be like" (R13).

\section{Anticipation of challenges.}

"I would be facing fears, challenges" (R12).

\section{Expectation of teamwork.}

"It would be teambuilding exercises" (R3).

\section{During the Activity: Critical Analysis of the Experience}

\section{Decreased nervousness and increased enjoyment during the activity.}

"I was really surprised at how fun it was- ice was broken very early on, got to know everyone and just had a great time" (R8.)

\section{Participated as a member of a team.}


Diversity of Research in Health Journal / Revue de la Diversité de la Recherche en Santé Vol 3, February / Février 2020 - ISSN 2561 - 1666 DOI: 10.28984/drhj.v3i0.296

"Everyone was getting engaged and worked together to complete a number of activities... everyone worked together as ONE big team" (R7).

\section{Learned to trust peers.}

"I felt more trust in my peers, having them catch me in fall and trust exercises" (R2).

\section{Able to work through challenges.}

"It was a good feeling when we did finish every task" (R3).

\section{After the Activity: New Perspectives Gained}

\section{Teambuilding skills are transferable and relevant to nursing.}

"Teambuilding and trust exercises are important and relevant to nursing practice- in order to work together you need good communication" (R11).

2. Importance of self-reflection when encountering new situations.

"Value being able to look back on actions and seeing how I felt" (R10).

\section{Increase in self-awareness- thoughts, feelings, and capabilities.}

"Being able to blindly trust people that I really didn't know that allowed me to feel like I can be more trusting and open to new people in the future" (R2).

"Got me out of my comfort zone which must also be done in reflection- caused me to think about my current thinking” (R5).

The themes identified at each stage of reflection indicate that the tango Tower challenge course and the practice of self-reflection assisted these first year nursing students in several areas of their learning. As identified in the literature, (Bartley et al., 2003; Garder and Flood, 2006; Speelman, 2013) these students became more self-aware in how they encounter new situations and improved on their communication and team-building skills.

A limitation of the research was the small sample size. It would have been beneficial to have more than 16 students who consented. A suggestion would be to obtain the consents earlier, before the activity has taken place. This initiative was only a one-time delivery, so it would also be beneficial to have the activity repeated for a few years, or perhaps to repeat it in the final year of the program in order to observe personal growth related to working as a member of a team.

\section{Conclusion}

This group of first-year nursing students had overall positive experiences which resulted in learning and self-awareness that occurred through reflective practice at various stages of the Tango Tower activity. These results could inform educators and facilitators in nursing and perhaps other health professions in promoting the use of the Tango Tower within their courses. 
Diversity of Research in Health Journal / Revue de la Diversité de la Recherche en Santé Vol 3, February / Février 2020 - ISSN 2561 - 1666 DOI: 10.28984/drhj.v3i0.296

Hence, the recent thrust toward health care professionals learning to work in interprofessional teams may provide opportunities for these challenge activities in educational programs.

\section{References}

Braun, V. \& Clark, V. (2006). Using thematic analysis in psychology. Qualitative Research in Psychology, 3, 77-101.

Gardner, E., \& Flood, J. (2006). The Impact of a One-Day Challenge Course Experience on the Life Effectiveness Skills of College Students. AORE.

Rohnke, K., Wall, J., Tait, C., \& Rogers, D. (2007). The complete ropes course manual. Dubuque: IA: Kendall Hunt.

Smith, M. R. (2016). Challenge courses, Zip Lines and Aerial Adventure Parks. Retrieved from Adventures Smith: www.adventuresmithinc.com

Speelman, E.A. (2013). Challenge Course Meta-Analyses (Doctoral Dissertation). Retrieved from https://athenaeum.libs.uga.edu/handle/10724/30024 